\title{
Review of the Establishment and Development of the Saengjeon-yesu-jae
}

\author{
Hee-Chul, Park (ja.un)1)
}

\begin{abstract}
This paper focuses on how the Sangjeon-yesu-jae (生前豫修齊) was formed and activated. Previous researches focused on the rites performed after death i.e the 49th memorial rite Sasipgujae and overlooked the Sangjeon-yesu-jae, which is the rites before death. This study introduces the Sangjeon-yesu-jae and its characteristics. The existing rites (e.g Surukjae, Youngsanjae, and Sasipgujae) represent the worship rituals of Buddhism while the Sangjeon-yesu-jae shows a rite which contains Buddhist ideology. In fact, it is performed as a rite to save the living from death and, eventually, to escape from karma through recitation of the Diamond sutra. This study suggests that the Sangjeon-yesu-jae involves the religious meaning and cultural values of the Buddhist rituals.
\end{abstract}

Keywords: Sangjeonyesujae, Ritual, Buddhism, Rite, Living

\section{Introduction}

Jae, in Buddhism, is an expression of religious pursuits in ceremonial form by ritualizing and symbolizing Buddhist ideas. That is, Jae-hoi (ritual gathering) is a ritual intended to deliver Buddhist teachings both the living and the dead.

Among the various Jae ceremonies, this Jae contains the prefix "Yesu", as in "Yesu-jae", which means one "cultivates himself/herself in advance" for afterlife. Moreover, to emphasize the fact that Yesu-jae is performed during one's lifetime, Saengjeon is added in the prefix, which means while living. Thus the name Saengjeon-yesu-jae. The other name is Yesu-siwang-saengchil-jae, originating from 'yesu-siwang-s aengchil-gyeong,' the main scripture of Jijang belief relating to the afterlife[1].

In Korea, Saengjeon-yesu-jae became a conventional ceremony for Buddhism during the Joseon Dynasty. Literature goes way back in the Goryeo Dynasty, however, ceremonies began during the leap month of the Joseon Dynasty and has continued to date. Even those who do not

Received(May 20, 2020), Review Result(1st: July 10, 2020, 2nd: August 28, 2020), Accepted(September 25, 2020)

1) (A research Student of the doctors Course) 04620 Department of Buddhist Art, Graduate School of Art, Dongguk University, 1-gil, Pildong-ro, Jung-gu, Seoul, Korea

email: wjd9632@hanmail.net 
believe in Siwang (ten kings) of the afterworld, they cannot reject performing the ceremony on good deeds as part of their Korean cultural duties. This paper reviews the history of the establishment and the development of Yesu-jae.

\section{History of Saengjeon-yesu-jae}

\subsection{Establishment of Saengjeon-yesu-jae}

The names used to describe Yesu-jae are different for each historical period. The commonly used name today is 'Saengjeon-yesu-jae' whereas Yesu-jae which, have been used during the Joseon Dynasty. Between the two, 'Saengjeon-yesu-jae' is more widely used.

The Siwang belief, which forms the foundation of 'Saengjeon-yesu-jae,' does not appear in Indian Buddhism. Instead, Siwang belief appears to have been born after Buddhism was introduced to China[2]. Around the time when Siwang belief was formed in China, Taoist belief had already taken root in China. Taoists believed that mystical holy powers governed the life and death of humanity. This belief, which is otherwise known as Tae-san belief based on the Tae-san (Tae-mountain), was combined with the Buddhist idea of hell when Buddhist scriptures were translated into Chinese after the introduction of Buddhism in China during the Huhan Dynasty.

Yeomra-wang (Yeomra-king), a transliteration of Yama, the ruler of the hell, and Taesan-bugun, which is unique to the Chinese Taoist belief, were combined to create the new idea of hell. This combination placed Taesan-bugun, a folk deity in China who governed the life of humanity, below Yeomra-dae-wang as a judge in the afterworld. This Siwang structure led to a clearer understanding of the Buddhist belief by the common populace in China and helped Buddhism to gain popularity.

In Korea records of Siwang belief appear in "Goryeosa (Goryeo history)" around 10thcentury.

Siwangsa (Siwang temple) was built the west corner of the palace. The iconography took a strange and convoluted appearance. It was to seek the help of the gods because of the ulterior purpose(Goryeosa, Volume 127, Yeoljeon, Volume 40)[3].

The above excerpt describes that Kim Chiyang constructed the Siwang temple during King Mokjong's reign (997-1009), and plotted against the king. Chiyang was plotting against the king. Generally, the rites of Siwang belief express the Buddhist teaching that Siwang of the afterworld will judge a person based on one's sins in the afterlife and that a person will go through the cycle of Samakdo (lower three realms). 
The Buddhist scripture explaining the "Buseol-yesu-siwang-saengchil-gyeong" emphasize readers not to the commit "ten evils and five sins but instead, give alms and make offerings in their daily lives. Even if one lacks the Buddhist belief of the faith in Siwang of the afterworld, performance of good deeds is a normative act for all people, which should not be rejected. It is difficult to accurately identify when Yesu-jae became a folk tradition of the leap month based on literatures. That is, even based on the scriptures related to Saengjeon-yesu-jae from the Joseon Dynasty, there is no description related to leap month and Yesu-jae. However, the hints on how this folk tradition came to be established during the Joseon Dynasty can be found outside the literatures. As a representative example, the basis for the establishment of Yesu-jae as a folk tradition can be found from how the people during the Joseon Dynasty made clothing for the dead (Sueui).

In the common world, leap month is said to be a good month to get married and a good month to make clothing for the dead (Sueui) because there is no restraints. At Bongeunsa (temple) of Gwangju, women from Seoul competitively visit to pray and place money in front of the Buddha each leap month. This continues incessantly throughout the leap month, and such prayer and offering are said to lead one to the heavenly world. Old women from all directions came together like the tidal waves. These folk traditions abound in majority of the temples located in Seoul and the countryside (Dongguksesigi, Yundal) during leap month[4].

The above material shows that the word, "clothing for the dead" (Sueui), was first used around the 17th century and became a representative folk tradition at that time. The leap month is a time for Siwang (ten kings) to practice self-cultivation and asceticism together. Hence, it is good time for people to worship and to make offerings to the entire Siwang at once. This religious behavior is inspired by people's wishes to clear their karmas of the past, present and future lives. These Buddhist rites during the leap month helped Buddhism become, and thereafter, hold the position of a strong and traditional religion worshiped by the general populace despite the continuous oppression and belittlement toward Buddhism which started during the Joseon Dynasty. With these background of old folk belief, Yesu-jae established itself as a traditional religious custom and became a typical profile of Buddhist belief of the late Joseon Dynasty and then an important axis of Buddhist rites.

\subsection{Establishment of Seangjeon-yesu-jae}

The encyclopedic definition of Yesu is to cleanse one's soul prior his death. Anyone should perform the good deeds and charitable activities in one's lifetime to secure a place in the 
heavenly paradise in the afterlife. Occasionally, Yesu replaces the word Yeoksu, while Jae represents Jae-gye, a prayer for a clean and pure soul. It differs from Jaesa, which is a memorial ceremony for the deceased.

It is called Yesu-jae because Yeoksu means to cleanse not only in advance but also in reverse. It means that the performance of ' $7.7 \mathrm{Jae}^{\prime}$ during one's lifetime is the opposite the performance of '7.7 Jae' after death. Yesu-jae is also called Jasu because it is a self-cleansing practice during one's lifetime, however, Jaesa can not be performed by the deceased. That is, Yesu-jae performance of one's own 49-Ja is advanced. prior to death. The self-cleansing practice traces its origin back to Jigang belief.

It is said that Jasu is necessary because the living who holds the ceremony gets $6 / 7$ parts of merits while the deceased receives only $1 / 7$ parts of such merits. Because of this imbalance, it is encouraged to hold one's own 49-Jae' to receive the full merits in one's lifetime.

Sudden death makes it impossible for the deceased to make the right decisions because of hearing incapability. Instead, the dead must rely on the emissary of the netherworld and be judged and sent to the next realm according to one's own karma. Performance of 49-Jae is the only way to help the deceased get good merits and have a good afterlife.

Yesu was described in the Sutras named "Bulseol-yesu-siwang-gyeong" which was also called Yesu-siwang-saengchil-gyeong, Siwang-saengchil-gyeong, Jijang-siwang-gyeong, or simply Siwang-gyeong[5]. According to the description of Yesu-jae in these Sutras, if people hold the ceremony to pray and make offerings at the Sambojeon (Three Jewels Pavilion) and Siwang-dan (alter of ten kings) every first day and the fifteenth day of the month, a registry of their names would be kept in the netherworld. Moreover, because of this registration, people are exempted from becoming a Jungeumsin (antara - bbava) for 49 days after death and instead, they are given passage directly to the heavens. However, it is strongly required not to miss any one of the seven Jae ceremonies while alive because missing one Jae is equal to being kept for one year as a Jungeumsin.

In the book of Yesu-siwang-saengchil-jae-eui-chanyo, edited and explained by Daewoo, the character representing 'life' appears everywhere. It leads to the possible assumption that the ceremony emphasizes the time while being alive and causes to be called Saengjeon(whil ebeing alive). Insum, in the book of Bulseol - kwanjeong - suwon - wangsaeng - sibang - jeongto gyeong[6] it is said that the endless merits are guaranteed if anyone follows the following practices; to abide by the Buddhist code of conduct and perceive the body as an illusion, to continue learning and self-cultivation toward the enlightenment of Bodhi, and to continuously invite many monks and to chant Sutras for good karma under the bright lanterns and 
decorated silky awnings for three weeks[7].

According to the records mentioned above, the current Saengjeon-yesu-jae was derived from Sobeon-jae which started in the early 16th century Joseon Dynasty as a traditional custom of leap month, up to the present time.

\section{Ceremonies and Foundational Sutras of Jijang Belief}

\subsection{Foundational Sutras of Jijang Belief}

Buseol-yesu-siwang-saengchil-gyeong, which is a foundational Sutras of Saengjeon-yesu-jae, says that Buddha gave Yeomra-cheonja the blessing of enlightenment to become a Buddha named Bohyeonwang-yeorae in the future world.

"Sakyamuni Buddha summoned congregation that in the future world Yeomra-cheonja would certainly become a Buddha and be called as Bohyeonwang-yeorae. (He) would be endowed with whole ten epithets of the Buddha, and the land would become that of, thereby being decorated majestically with all kinds of jewels and called Hwaeom filled with many Boddhisattvas." [Bulseol-yesu-siwang-saengchil-gyeong][8]

Serious crimes such as hurting one's parents, disgracing the Buddhist code of conduct, and killing animals lead to the punishment of being sent to the hell for five to ten Geop (endless period of time).

If anyone reads these Sutras and builds many statues of worship, such deeds would be written on the registry of karma which would please Yeomra-daewang. He would be released and reborn in a rich and noble family. His karma from sins would be excused[8]. As a vehicle to realize one's fortune in the future, Yesu-siwang-gyeong encourages people to participate in the Jae ceremony and maintain a religious belief that they could eventually lead a heavenly life in the future world.

Holding a Jae ceremony promises the deceased to pass the members of Siwang (ten kings) of the -world without obtaining their verdict, and to be sent straight to heaven. In ancient China, Taoism believed in the mysterious holy spirit and its governing power over life and death of people.

During the Huhan dynasty, people believed that there were four holy mountains in four directions. Among them, Tae-san (Tae mountain)' was occupied by the spirit of death which holds the record of people's life and death. Tae-san-bugun who lived in Tae-san was a messenger god. This idea developed into Tae-san belief[9]. 
When the Buddhist Sutras were translated into Chinese language in Huhan Dynasty, the Buddhist concept of hell was combined with Tae-san belief. That is why the word Tae-san-jiok (Tae-san hell) appeared frequently in the Sutras. Later in the period of the North and South Dynasties in China, the Buddhist concept of hell was embraced in a fuller scale. Yeomra-wang in Buddhism and Tae-san-bugun in Taoism combined and formed the mainstream Chinese belief of hell. Until then Tae-san-bugun had governed the life and death of people. However, after the merging of beliefs, Tae-san-bugun became one of the judges of the netherworld which held the lower position than Yeomra-dae-wang.

When Buseol-Yesu-siwang-saengchil-gyeong was published in the 9th century during the late Dang Dynasty, the concept of Jijang Boddhisattva, who was the savior in hell, and the concept of Si-wang were combined and formed the complete structure of Si-wang belief[9]. Myeongbu-siwang (ten kings in the world of the dead) belief, which was derived from the combination of Indian Yama-cheon (Yama-heaven) belief and Chinese Taoism, developed as the main concept and the background of Saengjeon-yesu-jae because it enabled the people to understand the structure of the hell-beings in the hell and to pray for the dead as a religious object. In Korea, the first literature writing about the Siwang belief appeared in 10th century. It was written in Goryeosa (history of Goryeo Dynasty) that Chiyang Kim during King Mokjong era had built the Siwang-sa (temple) at the northwestern corner of Gaesung castle[10]. The record of the construction of the Siwang-sa temple is a clear evidence that Siwang belief has taken roots during King Mokjong era in the Goryeo Dynasty. As mentioned earlier, after the publication of Bulseol-yesu-siwang-saengchil-gyeong in the 9th century during the late Dang Dynasty, it became clear that the belief of Siwang in the world of the dead was the combination of Jijang Boddhisattva and Siwang, and that the appearance of Siwang and their names were already known.

\subsection{Ceremonial Manuals of Joseon Dynasty}

The full-scale publication of the ceremonial manuals of Yesu-jae started in the Joseon Dynasty. 『Yesu-siwang-saengchil-jae-euichanyo and ${ }^{\mathbb{P}}$ Yesu-cheonwang-tong-eui』 were published as the ceremonial manuals with the descrip-tion of Jae and the ceremony was held accordingly . 『Yesu-siwang-saengchil-jae-euichanyo was a manual of Saengjeon-yesu-jae written on the basis of Bulseol-yesu-siwang-saengchil-gyeong by Song-dang Daewoo[11], a monk in mid-Joseon Dynasty. Among existing manuals of Saengjeon-yesu-jae, the woodblock-printed copy of 『Yesu-siwang-saengchi-jae-euichanyo』 published at Yeongcheon-sa (temple), Baekryeonsan in 
Seongcheon, Pyeongando in 1566 (King Myeongjong 21) is the oldest. Later three more editions were published at Songkwangsa in Suncheon, Jeonrado in 1574, at Kwangheungsa in Andong, Gyeongsangdo, in 1576, and Bowonsa in Seosan, Chungchungo, in 1577.

There had been some structural changes, for example, the Yeongcheonsa edition was initially consisted of 31 parts of the ceremonial procedure, but the Yongboksa edition (in 1632) was reduced to 25 parts. Finally, Seokmun-euibeom published in 1935 expanded the ceremonial procedure to 35 parts. The Yongboksa Edition seemed to be a single manual for the simple ceremony because it did not have the lower alter offering service parts which was very unique.

The Publication of ceremonial manuals was to streamline the various styles of ceremonies on the introductory process of Yesu-jae and to spread them out. The publication of Yesu-siwang-saengchil-jae-euichanyo seemed to establish the structured ceremonial procedure of Saengjeon-yesu-jae and to motivate its widespread dissemination. The sequence of Yesu-siwang-saengchil-jae-euichanyo is arranged in accordance with the published articles of Yesu-jae. Yesu-ae-chanyo and Seokmun-euibeom, both edited by An Jinho, were used as references. These three reference materials are the best-known manuals of Saengjeon-yesu-jae ceremony. Jogyesa Edition of Saengjeon-yesu-jae ceremony manual was published by Inmuk Seunim, who was the chairman of 『Buddhist』 ceremony of Korea Jogye Buddhist Sect. It was based on the documents that belonged to Ileung Seunim. This article describes the sequence recorded in the ceremonial manual without any changes as the result from the observation of Jogyesa Saengjeon-yesu-jae.

The main ceremony of Saengjeon-yesu-jae consists of the first part Tongseo-inyu and up to the 33th part of the Bosin-hoihyang. However, the parts are sometimes combined into the several groups with subject titles by Eosan who presides the ceremony.

It is more reasonable to think that the parts are combined for convenience because according to the manual, the ceremony consists of each individual part. Therefore, there may be differences in the number of groupings in Saengjeon-yesu-jae ceremony depending on the Eosan Seunim. Also, each Eosan Seunim may differ in organizing the sequence of the Buddhist dances and the types of acoustics.

The procedure of Saengjeon-yesu-jae ceremony is shown below.

Current Yesu-jae is based on Yesu-siwang-chiljae-euichangyo compiled by Songdang Daewoo, which appeared in Seokmun-euibeom[12]. In Seokmun-euibeom, the ceremonial procedure of Yesu-jae is composed and rearranged. Yesu-jae is differentiated from common Saengjeon-yesu-jae in ceremonial procedure. Siryeon-jeolcha is included in Saengjeon-yesu-jae but not in Yesu-jae. 
[Table 1] The Procedure of Saengjeon-yesu-jae Ceremony

Sinjung-jakbeop -- Guiebul-bulpae-ieun - Oeidaeryeong - Gwanyeok - Jojeon-jeoman - Unsudan

(building the sacred space) -- Sajadan - Sangdan (upper alter) (Samdan-gumok)

-- Jungdan (middle alter) (kings, judges, The Venerable) -- Hadan (lower alter), Gosadan

- Magudan - Hamhapso - Sisik - Bongsong.

\section{Conclusion}

Among the diverse Buddhist rituals passed down through the long Buddhist history, Saengjeon-yesu-jae is one of the rituals that had developed in China and Korea. Buddhist rituals can be deemed an important practice of asceticism, which expresses the religious aims of Buddhism. Thus, we studied the process by which Saengjeon-yesu-jae, which is an important axis of Korean Buddhist rituals currently performed, was established, and examined the meaning and development of Yesu-jae.

Saengjeon-yesu-jae is a ritual that releases the suffering mankind from malicious deeds to guide them to the Buddhist paradise. Under Jijang and Myungboo Shiwang belief systems, the living performs Jae to save the dead. While Yesu-jae was called various names in different literatures including "Shiwangsaengchiljae," "Yesuhui," "Saengjeon-yesu-jae," and "Yeoksu," the most commonly and widely used name is Yesu-jae to encapsulate its core function of having the living accumulate charitable deeds in advance for the dead. In fact, Yesu-jae was first practiced from the Koryoera, a fact shown through the scripture plates of Yesushiwangsaengchilgyung or historical records, but it became a popular practice from the Josun era. Yesu-jae's prominent practice during the Josun era can be seen from the multiple publications of ritual compendiums related to Yesu-jae during the Josun era.

In addition, the most representative historical records from which we can infer the actual practice of Yesu-jae are "Joongjongshillok" and "Seokmuneuibum," each is a historical record and ritual compendium. While the ritual compendium allows logical inference of the practice of Yesu- jae during the Josun Era, "Josunwangjoshillok" provides the most evident empirical proof. Therefore, by comparing the two records, it is possible to infer that the ritual compendium and actual practice had developed through the same process. This confirms that Yesu-jae, which was inherited by Korea from China, not only practiced the same ceremonial procedures but also maintained its original form for over a millennium. That is, the historical records prove that Yesu-jae is one of the representative Korean traditional rituals. Through these pertinent research projects, I will analyze the meaning of practicing Yesu-jae in more 
detail and study why certain practices have diverged, albeit partially, from the original form that was first practiced in Korea. Further research on Yesu-jae may reveal its religious and cultural meaning.

\section{References}

[1] Myeong ryeol No (Hyeiil-myeongjo), Comparison Review of Saengjeon-yesu-jae between the present and Joseon Dynasty, Chung-ang University, Ph.D dissertation, (2010)

[2] Tae-sik Han (Bo gwang), A Study for Religious Belief on the Commemorative Rites for Oneself, Journal of The Pure Land Buddhism Studies, (2014), Vol.22, pp.9-47.

[3] Goryeosa, (Goryeo history), Sutra, (1396), Vol.127, http://db.history.go.kr/KOREA/item/level.do? itemId $=$ kr\&types $=r$

[4] Suk Mo Hong, Dongguk-sesigi, http://encykorea.aks.ac.kr/Contents/Item/E0016268, May 1 (1849)

[5] Cheon-Jang, Bulseol-Yeomrawang-sugi-sajung-yeoksu-seangchil-jusaeng-jungto-gyeong, Sutra, (Mansokjang), Tang Dynasty. 9-10 century, Vol.150, pp.777-790, https://kabc.dongguk.edu/content/view?itemId=ABC_IT\& cate $=$ bookName\&depth $=3 \&$ upPath $=$ Z\&dataId=ABC_IT_K0682_T_001

[6] Śrīmitra, Gwanjeong-gyeong (FOSHUOGUANDINGQIWANERQIANSHENWANGHUBIQIUZHOUJING), Vol.12. https://kabc.dongguk.edu/m/content/seoji?cate=\&upPath=\&itemId=ABC_IT\&dataId=ABC_IT_K0174_T_001

[7] Goryeo-daejang-gyeong, Sutra, (1236-1251), Vol.10, https://abc.dongguk.edu/ebti/c1/sub1_2.jsp

[8] Bulseol-yesu-siwang-saengchil-gyeong, Sutra, (1718), Vol.1, https://kabc.dongguk.edu/content/pop_heje?dataId= ABC BJ H0275

[9] Jeong-hi Kim, A Study of Wang belief of Joseon Dynasty and Iconography of Myeongbujeon (Afterworld Pavilion), Korean Bulletin of Art History, (1991), Vol.4, pp.33-74, https:/drive.google.com/drive/u/1/folders/13D1mzXx972ILLkmj12aR9GY0eFyA2kAQ

[10] Seokmun-euibeom, Rituals, (1935), Vol.1, pp.156-215, http://encykorea.aks.ac.kr/Contents/Item/E0028419

[11] Myeong Ryeol No (Hyeiil-myeongjo), Yesu-jae, Korea: Essay publishing, (2011), https://www.aladin.co.kr/s hop/wproduct.aspx?ItemId=10985385

[12] Tae Sik Han, A Study for Religious Belief on the Commemorative Rites for Oneself, Journal of The Pure Land Buddhism Studies, (2014), Vol.22, pp.9-47. 